\title{
Abordagem comunicativa em sala de aula: uma autorreflexão docente
}

\section{Diullye Miola}

diullyemiola@gmail.com

orcid.org/0000-0001-8871-6238 Paraná (Unioeste), Toledo, Paraná, Brasil.

Gabriele Leske Engelmann gabrieleleske93@gmail.com orcid.org/0000-0001-8288-138X

\section{RESUMO}

O presente trabalho analisa as abordagens comunicativas a fim de desenvolvermos uma autorreflexão docente. As abordagens ocorreram por meio de uma atividade realizada pelo grupo PIBID, utilizando como metodologia as análises discursivas de Mortimer e Scott (2002), para verificar como ocorrem as interações entre estudantes e futuros professores de química. Para tal análise, realizamos leitura e discussão de um texto: "Identificação Genômica: o DNA Forense" como forma de contextualizar a química forense em uma sequência didática. Essa atividade serviu como base para o entendimento das análises discursivas existentes na interação entre estudantes de Ensino Médio de um Colégio da Rede Pública do Estado do Paraná e acadêmicos do subprojeto PIBID, os quais denominamos como pibidianos. As discussões foram gravadas com gravadores de áudio e depois transcritas para análise. Os métodos apresentados nas análises discursivas nos conduzem a uma autorreflexão da prática docente na interação de futuros professores de Química com estudantes do Ensino Médio de uma escola da rede pública de Toledo/PR. Como a atividade foi desenvolvida pelo grupo de acadêmicos do PIBID, um dos principais focos do projeto consistiu em permitir aos pibidianos vivências sobre práticas pedagógicas em sala de aula. Com isso, esta atividade permitiu a esses acadêmicos, por meio das abordagens comunicativas de Mortimer e Scott (2002), identificar os posicionamentos pedagógicos na discussão de um texto, a fim de analisar suas ações no decorrer da atividade.

PALAVRAS-CHAVE: Análises discursivas. Formação de professor. DNA Forense. 


\section{INTRODUÇÃO}

O projeto PIBID, Programa Institucional de Bolsa de Iniciação à Docência, permite adquirir conhecimentos do âmbito escolar e da pesquisa durante o período da graduação, sob a orientação de um docente da escola em que o projeto está em vigência. Assim, para as experiências obtidas no decorrer do projeto sobre a prática docente, salientamos a prática da pesquisa e as experiências vivenciadas, a busca de dados para resolver questões relevantes do cotidiano escolar, a reflexão dos dados para obter respostas aos problemas do ensino e compreensão da prática educativa como espaço de formação contínua (IBERNON, 2002).

Partimos da importância de se analisar a prática pedagógica, permitindo a ampliação do conhecimento profissional docente, em que é possível observar, estudar e identificar os pontos que apresentam fragilidades na ação didática. Entendemos que o conhecimento docente deve ir além da "teoria e prática", mas estas duas devem vincular-se com a procura de conhecimentos e métodos pertinentes, exigindo maiores esforços, em suma

[...] à necessidade de elaborar um conhecimento pessoal (um autoconhecimento) no interior do conhecimento profissional e de captar (de capturar) o sentido de uma profissão que não cabe apenas numa matriz técnica ou científica. Toca-se aqui em qualquer coisa de indefinível, mas que está no cerne da identidade profissional docente (NÓVOA, s/a, p.7).

Assim, como o PIBID visa à formação do professor, buscamos entender como ocorre a interação entre o que denominamos estudantes/pibidianos no contexto escolar, com uma atividade vinculada aos conteúdos do Plano de Trabalho Docente ministrados pela professora supervisora do PIBID/Química.

Para esta atividade, realizamos a leitura de um texto que aborda a relevância do avanço da pesquisa em perícias forenses, com assuntos relativos ao DNA, buscando conforme Rosa, Silva e Galvan (2014, p.1), uma "[...] tentativa de fazer os estudantes se sentirem motivados e interessados a buscar o conhecimento". Segundo os autores sobre o ensino envolvendo a química forense,

\footnotetext{
Essa ciência é um tema que atrai a atenção dos grupos mais distintos, [...] quando inserida no processo educacional, torna-se uma importante ferramenta de divulgação da ciência em geral, obtendo-se, com isso, a descentralização desejada para que esta se estenda além dos limites escolares (ROSA; SILVA; GALVAN, 2014, p.2).
}

No contexto da leitura e discussão deste texto, analisamos as abordagens comunicativas (entre estudantes e pibidianos) utilizadas no decorrer da aula de Química, a fim de realizarmos uma auto análise de um viés construtivo para a formação do professor, por meio da metodologia da Interação Discursiva, que consiste em uma "[...] ferramenta para analisar a forma como os professores podem agir para guiar as interações que resultam na construção de significados em salas de aula de ciências" (MORTIMER; SCOTT, 2002, p.284).

Acreditamos que o processo de aprendizagem não pode ser resumido em "troca de conceitos", ou seja, substituição de concepções que o estudante já possui por conceitos científicos. Mas, este processo de aprendizagem deve ser realizado em um espaço que haja comunicação para que as diferentes perspectivas culturais sejam discutidas propiciando novos significados a partir de um crescimento mútuo. 
Partindo disto, as Interações Discursivas constituem o processo de construção de significados nas aulas de ciências por meio da interação professor/estudante (MORTIMER; SCOTT, 2002).

A análise das Interações Discursivas propicia ao docente uma análise da sua prática docente a fim de resultar na construção de significados nas aulas de ciências, por meio da interação professor/estudante. Esta é uma importante ferramenta, uma vez que, a sala de aula não é apenas um espaço constituído de materiais (mesa, cadeira e quadro), mas é nela em que se estabelece e se efetivam as relações entre professor/estudante, por meio da comunicação. Assim, "[...] a comunicação é exercida pelo recurso da língua, que é um conjunto de signos e regras [...] a linguagem é mais que o registro do pensamento, ela é instrumento de mediação do processo de ensino" (SOUZA; CAMPOS; BENITE, 2014, p.150).

Partindo disso, é possível construir uma nova reflexão sobre a prática propriamente dita. Com isso, "[...] num processo de auto-formação, de reelaboração de novos saberes iniciais em confronto com sua prática vivenciada" (NUNES, 2001, p.30), tendo em vista que o professor é responsável pela mediação dos conhecimentos científicos, e assim, a linguagem e a análise desta, é um importante instrumento de trabalho para o docente.

Com isso, realizamos uma atividade para verificar, por meio do processo das análises discursivas, a prática pedagógica de futuros professores de química do grupo PIBID. Buscamos entender a interação entre professor e estudantes no decorrer da leitura e discussão de um texto com o tema envolvendo a química forense.

\section{MÉTODOS}

Na prática pedagógica, como proposta do grupo PIBID/Química, visando a formação do professor e a forma de interação deste com os estudantes, realizamos uma pesquisa qualitativa em que os professores podem incorporar em sua profissão, a investigação com os estudantes, compreendendo vários pontos de vista, identificados nos modos de condução da atividade.

Com isso, realizamos a atividade no Colégio Jardim Porto Alegre do município de Toledo/PR. Participaram desta atividade 28 estudantes do 1 을 Ano do Ensino Médio Técnico Integrado em Administração, na qual a disciplina de Química está presente.

A atividade para a análise da prática docente dos integrantes do grupo PIBID/Química como futuros professores, consiste em coleta de informações a partir da discussão e leitura do texto "Identificação genômica - o DNA forense" de Watson e Berry (2005) conforme reescrito no Quadro 1. 
Quadro 1 - Transposição do texto utilizado para as discussões

\section{IDENTIFICAÇÃO GENÔMICA: O DNA FORENSE}

Em 1998, Marvin Lamont Anderson, de 34 anos de idade, foi solto na penitenciária Estadual da Virgínia. Ele estivera preso por quinze anos, quase toda a sua vida adulta, condenado por um crime hediondo; o estupro brutal de uma jovem em julho de 1982. A promotoria apresentara um caso totalmente inequívoco: a vítima reconheceu Anderson em uma fotografia e identificou-o numa fileira de outros suspeitos e no tribunal. Anderson foi considerado culpado de todas as acusações e recebeu sentenças consecutivas que totalizaram mais de duzentos anos.

Um caso inequívoco. Mas quem sabe um advogado de defesa mais hábil conseguisse rebater o esforço da promotoria em arrumar uma arapuca contra o réu. A prisão de Anderson foi baseada exclusivamente nos depoimentos da vítima (branca) á polícia, que disse que o agressor (negro) se gabara de "ter uma mulher branca". Até onde as autoridades sabiam, Anderson era o único negro da cidade com uma namorada branca. De todas as fotografias de arquivo que a vítima examinou, somente a de Anderson era colorida. E, de todos os homens cujas fotos Ihe foram mostradas, só ele foi incluído na linha de identificação. Ainda que tenha sido provado que a bicicleta usada pelo agressor fora furtada trinta minutos antes da ocorrência por outro homem, John Otis Lincoln, o advogado de Anderson não quis convocar Lincoln como testemunha.

Cinco anos após o julgamento, Lincoln confessou o crime sobre juramento, mas o juiz acusou-o de mentiroso e se recusa a tomar providência. Anderson enquanto isso, continuava protestando sua inocência e solicitou que fosse feita uma análise do DNA das evidências físicas encontradas na cena do crime. Mas informaram-no que tudo fora destruído, em conformidade com os procedimentos usuais. Foi então que Anderson entrou em contato com os advogados do Innocence Project, um grupo de atraíra atenção nacional usando análises do DNA para estabelecer provas definitivas de culpa ou inocência em processos criminais. Enquanto o Innocence Project estudava o pedido de Anderson, ele foi solto sob condicional. Se não cometer nenhuma infração, permanecerá em condicional até 2088 - ou seja, certamente até o fim da vida.

No final, o que o salvou foi um desleixo da perita que, em 1982, realizara uma análise inconclusiva de grupo sanguíneo com material obtido no local do crime: ela se esquecera de devolver as amostras às autoridades competentes, que as destruíram como medida de rotina. Com isso, as amostras ainda existiam quando Anderson solicitou um novo exame. Mas o diretor do departamento de Justiça Criminal da Virgínia indeferiu o pedido, argumentando que constituía um "precedente indesejável". Graças a uma nova legislação; no entretanto, os advogados do Innocence Project obtiveram uma liminar determinando que os testes fossem realizados. Em dezembro de 2001, os resultados provaram categoricamente que Anderson não poderia ter sido o agressor. A "impressão genômica" do DNA da cena do crime combinava com a de Lincoln. Esse acabou sendo condenado e Anderson foi perdoado pelo governador da Virgínia, Mark Warner. 
Realizamos a leitura do texto, junto com os estudantes, proporcionando a estes um contato com o tema: DNA forense, fazendo parte da sequência didática das aulas de Química, ao conteúdo de ligações químicas. A leitura foi realizada com os estudantes com pausas para debate. As falas dos estudantes e dos pibidianos foram gravadas com gravadores de áudio e transcritas, conforme as regras de transcrição descritas no Quadro 2, partindo das discussões com os estudantes.

Quadro 2 - Principais sinais acordados em uma transcrição no Brasil

\begin{tabular}{c|c} 
Sinais & Normas acordadas em Transcrição de dados \\
\hline$\ldots$ & Para indicar qualquer tipo de pausa \\
\hline$($ ) & Para indicar hipótese do que se ouviu \\
\hline$(())$ & Para inserção de comentários do pesquisador \\
\hline$::$ & Para indicar truncamento de palavras por exemplo " o pro/ ... o \\
procedimento".
\end{tabular}

Fonte: Estudo comparado dos padrões de concordância em variedades brasileiras, europeias e africanas coordenada, por Silvia Rodrigues Vieira e Maria Antónia Ramos Coelho da Mota (s/a).

Para a transcrição utilizamos as siglas E1 a E28 para os estudantes, PS para a professora supervisora de Química do projeto PIBID e M1 a M6 para os pibidianos. Ao separarmos os trechos, codificamos conforme a sequência em que esses aparecem, seguindo o referencial utilizado de análises discursivas.

No presente trabalho, realizamos uma pesquisa qualitativa que do viés pedagógico consiste em oferecer "[...] uma oportunidade para fazer emergir pontos de vista dispares e habitualmente desconhecidos" (BOGDAN; BIKLEN, 1994, p. 291), os quais, analisados nas falas dos futuros professores, conduzem à interpretações da própria prática docente em questão. Pois, a pesquisa qualitativa na formação de professores,

É, sim, um método de investigação que procura descrever e analisar experiências complexas. Partilha semelhanças com os métodos de relações humanas na medida em que, como parte do processo de recolha dos dados, devemos escutar corretamente, colocar questões pertinentes e observar detalhes (BOGDAN; BIKLEN, 1994, p. 291).

A abordagem qualitativa, aplicada pedagogicamente, não constitui nenhuma técnica terapêutica, nem uma técnica de relações humanas. Como forma de analisar a própria prática docente, podem ser utilizados os cinco aspectos interrelacionados (Quadro 3), os quais focalizam o papel do docente em sala de aula. Por meio desses aspectos, é possível "[...] analisar a forma como os professores 
podem agir para guiar as interações que resultam na construção de significados em salas de aula de ciências" (MORTIMER; SCOTT, 2002, p. 284).

Quadro 3 - Estrutura analítica da análise da dinâmica discursiva nas aulas de ciências.

\begin{tabular}{|c|c|c|c|}
\hline \multicolumn{4}{|c|}{ Aspectos da Análise } \\
\hline Foco do ensino & 1. & Intenções do professor & 2. Conteúdo \\
\hline Abordagens & \multicolumn{3}{|c|}{ 3. Abordagem comunicativa } \\
\hline Ações & 4. & $\begin{array}{l}\text { Padrões de interação } \\
\text { professol }\end{array}$ & 5. Intervenções do \\
\hline
\end{tabular}

Fonte: MORTIMER e SCOTT (2002, p. 285).

Contudo, para o desenvolvimento deste trabalho, utilizamos o aspecto "abordagem comunicativa", baseado na metodologia de análise da dinâmica discursiva nas aulas de ciências de Mortimer e Scott (2002). A análise do discurso "[...] tem por objetivo caracterizar as formas como professores interagem com alunos no processo de construção de significados, pelo uso da linguagem e outros modos de comunicação" (AMARAL; MORTIMER, 2011, p. 245).

Partindo disto, a abordagem comunicativa fornece a perspectiva de como o professor trabalha as intenções e os conteúdos em sala de aula. Os autores apresentam quatro classes de abordagem comunicativa que definem o discurso entre estudante/professor ou entre os próprios estudantes em duas dimensões: dialógica/de autoridade e interativo/não-interativo (Quadro 4).

\begin{tabular}{c|c|c}
\multicolumn{2}{c}{ Quadro 4 - Quatro classes de abordagem comunicativa } \\
& INTERATIVO & NÃO-INTERATIVO \\
\hline DIALÓGICO & $\begin{array}{c}\text { a. Interativo / } \\
\text { Dialógico }\end{array}$ & $\begin{array}{c}\text { b. Não-interativo / } \\
\text { Dialógico }\end{array}$ \\
\hline DE AUTORIDADE & $\begin{array}{c}\text { c. Interativo / de } \\
\text { autoridade }\end{array}$ & $\begin{array}{c}\text { d. Não-interativo / de } \\
\text { autoridade }\end{array}$
\end{tabular}

Fonte: MORTIMER e SCOTT (2002, p. 288).

Os autores definem cada classe como:

Interativo/dialógico: professor e estudante exploram ideias, formulam perguntas autênticas e oferecem, consideram e trabalham diferentes pontos de vista.

Não-interativo/dialógico: professor reconsidera, na sua fala, vários pontos de vista, destacando similaridade e diferenças.

Interativo/de autoridade: professor geralmente conduz os estudantes por meio de uma sequência de perguntas e respostas, com o objetivo de chegar a um ponto de vista específico.

Não-interativo/de autoridade: professor apresenta um ponto de vista específico. (MORTIMER; SCOTT, 2002, p. 288, grifos dos autores).

Nessa perspectiva, para a análise da abordagem comunicativa que utilizamos em sala de aula, procuramos responder às duas questões: de que forma interagimos com os estudantes? Levamos em consideração as concepções dos estudantes para a construção das ideias científicas no decorrer da aula? 
Para o desenvolvimento da análise da prática pedagógica, dividimos as discussões do texto em episódios. O episódio consiste em "[...] um conjunto de enunciados que cria o contexto para a emergência de um determinado significado ou de alguns significados relacionados" (AMARAL; MORTIMER, 2011, p. 257). E, em cada um deles, conforme o assunto de cada episódio, analisamos a abordagem comunicativa, na interação estudante-pibidiano.

\section{RESULTADOS E DISCUSSÕES}

A atividade consistia na leitura do Texto "Identificação genômica - o DNA forense", como tema para o conteúdo de ligações químicas, assim, ao discutir este texto, salientamos que as pesquisas em envolvem avanços em química forense são essenciais para a elucidação de crimes e identificação de suspeitos. Com isso, na discussão deste contexto, iniciamos os conteúdos de ligação química e solicitamos a identificação dos tipos de ligações presentes na estrutura do DNA (da tradução do inglês: ácido desoxirribonucleico).

Para o desenvolvimento desse trabalho, não analisamos se a atividade promoveu conhecimento para os estudantes, mas analisamos as abordagens comunicativas do professor e pibidianos a partir da discussão com os estudantes do Ensino Médio, conforme já discutimos anteriormente. Para os episódios, apresentamos os trechos das análises em que são apresentadas as falas da professora e pibidianos são analisados conforme o foco deste trabalho partindo dos contextos, os quais provêm da interação com os estudantes. Com isso, embora não analisássemos a fala dos estudantes, estas são essenciais para a definição de como foi a abordagem do professor sendo apresentadas em conjunto com as falas deles.

No decorrer da atividade, explicamos brevemente os encaminhamentos de cada episódio.

Episódio 1: Como reconhecer um suspeito?

Com a discussão do texto mais especificamente na leitura do primeiro trecho, emergiram aspectos iniciais sobre o crime e suas possíveis formas de elucidação. O Quadro 5, mostra a transcrição das discussões analisando a abordagem comunicativa.

Quadro 5-Como reconhecer um suspeito?

\begin{tabular}{|c|c|c|}
\hline $\begin{array}{l}\text { Quem } \\
\text { Fala }\end{array}$ & Trecho & $\begin{array}{l}\text { Abordagem } \\
\text { comunicativa }\end{array}$ \\
\hline M3 & Então... o que que aconteceu aqui? & $\begin{array}{c}\text { Interativo/de } \\
\text { autoridade (I/A1) }\end{array}$ \\
\hline E1 & Ele estuprou uma mulher. & \\
\hline M3 & $\begin{array}{c}\text { Um homem foi acusado de ser... éh:: de ter } \\
\text { estuprado uma moça... e ele foi reconhecido pela... } \\
\text { pela vítima? }\end{array}$ & $\begin{array}{l}\text { Interativo/dialógico } \\
\text { (I/D1) }\end{array}$ \\
\hline E2 & É... pelo exame que tinha por dentro do sêmen. & \\
\hline M3 & $\begin{array}{l}\text { Aqui diz que ela reconheceu por foto... Então por } \\
\text { fotografias e por onde eles... éh:: na plateia ele foi }\end{array}$ & $\begin{array}{l}\text { Não interativo/de } \\
\text { autoridade (NI/A1) }\end{array}$ \\
\hline
\end{tabular}




\begin{tabular}{|c|c|c|}
\hline $\begin{array}{l}\text { Quem } \\
\text { Fala }\end{array}$ & Trecho & $\begin{array}{l}\text { Abordagem } \\
\text { comunicativa }\end{array}$ \\
\hline & $\begin{array}{c}\text { visto e dai foi acusado de ter sido ele que fez o } \\
\text { estupro. }\end{array}$ & \\
\hline M6 & $\begin{array}{c}\text { E não diz até então se foi feito algum exame ou } \\
\text { não...ela só reconheceu ele. }\end{array}$ & $\begin{array}{l}\text { Não interativo/de } \\
\text { autoridade (NI/A2) }\end{array}$ \\
\hline M3 & $\begin{array}{l}\text { Isso... e a gente pode assim... por exemplo... } \\
\text { reconhecer e comprovar assim... ele pegou mais } \\
\text { de } 200 \text { anos de prisão... Então será que pela } \\
\text { fotografia a gente pode ter certeza? }\end{array}$ & $\begin{array}{l}\text { Interativo/dialógico } \\
\text { (I/D2) }\end{array}$ \\
\hline E3 & Não. & \\
\hline M3 & Foi a vítima que reconheceu... não foi? & $\begin{array}{c}\text { Interativo/de } \\
\text { autoridade (I/A2) }\end{array}$ \\
\hline E3 & $\begin{array}{l}\text { Vai que ele tem irmão gêmeo ou é uma pessoa } \\
\text { parecida com ele. }\end{array}$ & \\
\hline M3 & $\begin{array}{c}\text { Isso... as vezes pode ter alguma pessoa parecida } \\
\text { ou... [...] ela (a vítima) pode estar nervosa e se } \\
\text { confundir... Então que que será que é preciso fazer } \\
\text { para... para ver quem é o culpado? }\end{array}$ & $\begin{array}{c}\text { Interativo/dialógico } \\
\text { (I/D3) }\end{array}$ \\
\hline E3 & $\begin{array}{l}\text { Fazer exame de sêmen... para ver se o sêmen é } \\
\text { dele... }\end{array}$ & \\
\hline E2 & Compara... para ver se é compatível. & \\
\hline E3 & É... compatível... isso & \\
\hline
\end{tabular}

Consideramos as codificações para as abordagens comunicativas conforme: (I/D) Interativo Dialógico; (I/A)- Interativo de autoridade; (NI/A) - Não Interativo de autoridade; (NI/D) - Não interativo dialógico.

FONTE: Autoria própria (2017).

Iniciamos a discussão do episódio perguntando características do crime que levaram a condenação de um homem injustamente. Em seguida, buscamos o entendimento dos estudantes sobre indícios de identificação do suspeito e de que forma este contexto foi apresentado no texto.

A análise da interação com os estudantes, especificada no episódio 1, apresentou três tipos de abordagens comunicativas:

- Utilizamos o discurso I/A, em que identificamos trechos que apresentam interação de maneira não dialógica, enfatizando o que o texto nos apresenta que o suspeito foi reconhecido pela vítima (I/A2);

- No discurso I/D, conduzimos o diálogo explorando as ideias que os estudantes possuem sobre o reconhecimento do suspeito acusado, conforme detalhes apresentados no texto além da suposta identificação da vítima, trabalhando com os pontos de vistas dos mesmos;

- Nas interações (NI/A1) e (NI/A2), sentimos a necessidade de expor o que interpretamos sobre o texto. Quando o estudante E2 afirma: "/.../exame que tinha por dentro do sêmen" poderíamos questionar os motivos que levaram este estudante a esta interpretação mesmo esta sendo passível de análise, pois não é apresentado este exame para elucidação do estupro no texto. Mas em contrapartida, 
apresentamos nossa própria interpretação explicativa e, deixamos transparecer a não concordância da fala dele segundo o texto.

Episódio 2: A cor da pele pode ser motivo para acusar um indivíduo?

O texto discutido apresenta diversos indícios de que o suspeito foi acusado devido a sua cor da pele. Sobre estas informações, os estudantes mencionam que a cor da pele (negra) influenciou a vítima a acusar o suspeito, e indicaram que na época em que ocorreu este caso de estupro, o racismo interferia diretamente para supor a identificação de suspeitos. No Quadro 6, apresentamos a análise desse episódio.

Quadro 6-A cor da pele pode ser motivo para acusar um indivíduo?

\begin{tabular}{|c|c|c|}
\hline Quem Fala & Trecho & $\begin{array}{l}\text { Abordagem } \\
\text { comunicativa }\end{array}$ \\
\hline M3 & $\begin{array}{c}\text { O que que a gente pode observar neste } \\
\text { parágrafo? }\end{array}$ & $\begin{array}{c}\text { Interativo/dialógico } \\
\text { (I/D4) }\end{array}$ \\
\hline E4 & $\begin{array}{l}\text { Que ele é uma pessoa negra... ai já é meio que } \\
\text { acusado então pelas pessoas... }\end{array}$ & \\
\hline E2 & $\begin{array}{c}\text { Nessa época já tinha um preconceito maior } \\
\text { (_) Tem mais morenos do que brancos na } \\
\text { cadeia... }\end{array}$ & \\
\hline M3 & $\begin{array}{c}\text { Então pesou um pouco mais o lado do racismo } \\
\text { né? }\end{array}$ & $\begin{array}{c}\text { Interativo/ de } \\
\text { autoridade (I/A3) }\end{array}$ \\
\hline M3 & $\begin{array}{c}\text { Além dele ser o único negro que eles } \\
\text { conseguiram identificar na cidade... ela falou já } \\
\text { que por ela ser branca... um negro foi... éh:: que } \\
\text { abusou dela... mas isso será que é um indício... } \\
\text { que o negro abusa? }\end{array}$ & $\begin{array}{l}\text { Interativo/dialógico } \\
\text { (I/D5) }\end{array}$ \\
\hline Estudantes & Não & \\
\hline M3 & Não né... & $\begin{array}{l}\text { Não interativo/ de } \\
\text { autoridade (NI/A3) }\end{array}$ \\
\hline \multirow[t]{2}{*}{ M3 } & $\begin{array}{c}\text { A gente pode falar que a cor que fez levar ele a } \\
\text { prisão? }\end{array}$ & $\begin{array}{c}\text { Interativo/dialógico } \\
\text { (I/D6) }\end{array}$ \\
\hline & $\begin{array}{l}\text { ((os estudantes ficaram cochichando, os } \\
\text { pibidianos e a professora chamam atenção e o } \\
\text { foco do diálogo é alterado)) }\end{array}$ & \\
\hline M3 & Então ali... o que aconteceu com a bicicleta? & $\begin{array}{c}\text { Interativo/de } \\
\text { autoridade (I/A4) }\end{array}$ \\
\hline E2 & Foi furtada minutos antes. & \\
\hline M3 & $\begin{array}{l}\text { Isso... então a bicicleta pode ter sido usada... } \\
\text { para... o agressor lá chegar até a moça... mas } \\
\text { não era mais dele pois ela tinha sido furtada. }\end{array}$ & $\begin{array}{l}\text { Não interativo/de } \\
\text { autoridade (NI/A4) }\end{array}$ \\
\hline
\end{tabular}

Fonte: Autoria própria (2017).

No Episódio 2, as discussões embora conduzidas pelos estudantes ao remeter ao assunto sobre racismo, constatamos:

- Por meio do discurso I/A, apontamos nossa própria interpretação do texto (I/A3) além do fato de que houve uma pausa no meio das discussões, em que a professora de Química chama atenção de um pequeno grupo de estudantes que estavam conversando, com esta 
pausa, houve mudança de foco das discussões para a bicicleta do suspeito (I/A4) não permitindo que os estudantes terminassem de desenvolver o discurso inicial sobre o racismo;

- Por meio das interações I/D trabalhamos com os pontos de vista dos estudantes e o entendimento dos mesmos sobre o texto;

- Com as interações NI/A além de concordarmos com a negação dos estudantes (NI/A3), sintetizamos as ideias discutidas no Episódio 3 (NI/A4). Acreditamos que este fechamento deveria ter sido feito pelos próprios estudantes, para que os mesmos conduzissem suas ideias ao entendimento do caso.

Episódio 3: O que contém no DNA?

Ao dar continuidade a leitura, interrompemos o estudante logo que o texto menciona sobre o DNA, para explorar o que os mesmos entenderam sobre o assunto. O texto informa apenas a sigla "DNA" não fornecendo significado da mesma. O Quadro 7 sintetiza a discussão e as abordagens comunicativas utilizadas nesse episódio.

Quadro 7-O que contém no DNA?

\begin{tabular}{|c|c|c|}
\hline Quem Fala & Trecho & $\begin{array}{l}\text { Abordagem } \\
\text { comunicativa }\end{array}$ \\
\hline M3 & $\begin{array}{c}\text { Só um pouquinho... Então o que é o exame de } \\
\text { DNA? O que vocês entendem quando pensam no } \\
\text { DNA? }\end{array}$ & $\begin{array}{l}\text { Interativo/de } \\
\text { autoridade (I/A5) }\end{array}$ \\
\hline M6 & Vocês têm biologia esse ano? & $\begin{array}{c}\text { Interativo/ de } \\
\text { autoridade (I/A6) }\end{array}$ \\
\hline $\mathrm{E} 2$ & Não o técnico não tem Biologia. & \\
\hline E6 & Não tem Biologia? & \\
\hline E2 & Esse ano não... só no terceiro e quarto ano. & \\
\hline E7 & Graças a Deus ((fala baixinho)) & \\
\hline M3 & O que é o DNA? & $\begin{array}{c}\text { Interativo/dialógico } \\
\text { (I/D7) }\end{array}$ \\
\hline E2 & $\begin{array}{c}\text { É um exame de sangue que pode... éh:: } \\
\text { comprovar éh:: áh:: a célula... amostra de } \\
\text { sangue... a pessoa... eu não sei }\end{array}$ & \\
\hline M3 & M3: Quem mais tem alguma ideia? & $\begin{array}{c}\text { Interativo/dialógico } \\
\text { (I/D8) }\end{array}$ \\
\hline E8 & É uma célula & \\
\hline M3 & É uma célula? Que tipo de célula? & $\begin{array}{l}\text { Interativo/dialógico } \\
\text { (I/D9) }\end{array}$ \\
\hline E8 & de sangue & \\
\hline E9 & Não é só sangue & \\
\hline E2 & $\begin{array}{l}\text { é molécula ((a risos, pois os estudantes não } \\
\text { conseguem definir o que é o DNA)). }\end{array}$ & \\
\hline M3 & $\begin{array}{c}\text { Quando a gente quer saber se... um determinado } \\
\text { homem ou uma determinada mulher é pai ou } \\
\text { mãe de uma pessoa? }\end{array}$ & $\begin{array}{l}\text { Interativo/dialógico } \\
\text { (I/D10) }\end{array}$ \\
\hline Estudantes & $D N A$ & \\
\hline M3 & mas por que eu posso fazer o DNA? & $\begin{array}{c}\text { Interativo/dialógico } \\
\text { (I/D11) }\end{array}$ \\
\hline
\end{tabular}




\begin{tabular}{|c|c|c|}
\hline Quem Fala & Trecho & $\begin{array}{l}\text { Abordagem } \\
\text { comunicativa }\end{array}$ \\
\hline E2 & Tipo sanguíneo & \\
\hline E1 & para (ver as) características & \\
\hline E2 & características dos pais & \\
\hline M3 & o que contém no DNA? & $\begin{array}{c}\text { Interativo/dialógico } \\
\text { (I/D12) }\end{array}$ \\
\hline E10 & tem as características dos seus pais & \\
\hline M3 & $\begin{array}{c}\text { Contém as características que você herda e suas } \\
\text { próprias características... O DNA de uma pessoa... } \\
\text { por exemplo... o meu DNA vai ser igual o dela? }\end{array}$ & $\begin{array}{l}\text { Interativo/dialógico } \\
\text { (I/D13) }\end{array}$ \\
\hline Estudantes & Não. & \\
\hline M3 & $\begin{array}{c}\text { Então cada indivíduo... tem um DNA } \\
\text { diferente...que é isso que dá as nossas } \\
\text { características... a cor do cabelo... cor dos olhos... } \\
\text { então tudo está contido no DNA... então ele } \\
\text { solicitou o exame de DNA... porque ele já falou } \\
\text { que não era ele o culpado... ele... ó ali... fala que } \\
\text { ele fez sob juramento que ele não era o culpado... } \\
\text { mas mesmo assim eles não queriam nem saber... } \\
\text { falavam que ele era o culpado e pronto... Então ai } \\
\text { que ele fez... é solicitou o exame de DNA... porque } \\
\text { por meio do DNA ele podia provar que não era } \\
\text { ele... então pode continuar }\end{array}$ & $\begin{array}{c}\text { Não } \\
\text { interativo/dialógico } \\
\text { (NI/D1) }\end{array}$ \\
\hline & ((a estudante continuou a leitura)) & \\
\hline
\end{tabular}

Fonte: Autoria própria (2017).

Iniciamos a discussão do Episódio 3 questionado os estudantes sobre o DNA mencionado no texto. Mas antes mesmo que os estudantes respondessem perguntamos a eles sobre a disciplina de biologia, uma vez que, segundo as Orientações Nacionais para o Ensino Médio, o DNA faz parte do currículo desta disciplina.

\footnotetext{
Um tema de importância central no ensino de Biologia é a origem e evolução da vida [...] O aluno deve compreender como as informações genéticas codificadas no DNA definem a estrutura e o funcionamento das células e determinam as características dos organismos [...] Cabe estimular o aluno a avaliar as vantagens e desvantagens dos avanços das técnicas de clonagem e da manipulação do DNA, considerando valores éticos, morais, religiosos, ecológicos e econômicos (BRASIL, 2006, p. 24).
}

Acreditamos que o DNA pode ser abordado na disciplina de Química, mas acreditamos também que a conceitualização propriamente dita do DNA parte da disciplina de biologia. Segundo as Orientações Nacionais para o Ensino Médio os conhecimentos de Química para o DNA podem ser abordados em

[...] comparação entre textos científicos e de comunicação ligados a teorias raciais do século XIX até as dos anos 1950 do século XX, com as comunicações científicas sobre o DNA do século XXI, presentes em várias Fontes; [...] discussão sobre Bioética, eugenia, DNA, colesterol, drogas (BRASIL, 2006, p. 127-128).

A atividade realizada sobre DNA pode ser desenvolvida tanto na biologia como na química, embora as Orientações determinem que os conceitos sejam 
trabalhados na biologia e a contextualização na química. Entendemos que, assim como na biologia pode haver contextualização deste assunto, podemos trabalhar também conceitos na parte de bioquímica, na disciplina de química.

Com isso, tendo em vista que a turma na qual a atividade foi realizada não é do Ensino Médio Regular e, sim do Ensino Médio Profissional em Administração, os estudantes não possuem a disciplina de biologia nas ementas da 1a Série, o que justifica a não apresentação de ideias conceituais sobre DNA, apenas ideias de senso comum.

Com base no exposto sobre os conhecimentos de Química, podemos atribuir que o texto discutido para o desenvolvimento desta atividade, pode ser atribuído à disciplina de Química, pois esta deve ser contextualizada. O tema tratado é um caso que ocorreu em 1998 (século XX) em que havia muitas discussões sobre teorias raciais. Souza (2016) afirma que nas primeiras décadas do século XX havia muitos debates sobre miscigenação racial no Brasil e no exterior,

[...] as primeiras décadas do século XX se caracterizaram pela importância que a questão racial alcançou no cenário internacional, especialmente pela estreita associação que esse tema apresentava nas discussões sobre o futuro das nações, das identidades nacionais, de sua força política e de sua capacidade de se impor perante outras nações (SOUZA, 2016, p. 612).

Na sequência, voltamos a questionar os estudantes sobre o DNA, explorando suas ideias e oferecendo-lhes, por meio das discussões, subsídios para chegassem ao entendimento de DNA.

- Utilizamos o discurso I/A, questionando os estudantes quanto ao DNA mencionado no texto (I/A4), mas antes mesmo que os estudantes respondessem questionamos em relação à disciplina de biologia (I/A5), de modo a justificar o "não conhecimento" científico dos conceitos de DNA;

- Nos discursos I/D, promovemos diálogos para expandir as ideias nas discussões e, eles mesmos, atribuem significados para a definição de DNA conforme conhecimentos prévios. Ainda na dimensão dialógica, questionamos os estudantes sobre a necessidade de exames de DNA (I/D11);

- Por meio da interação NI/D, fechamos o Episódio 3 reconsiderando as ideias dos estudantes e indicando que em exames de DNA são identificadas características pessoais, que no caso são utilizadas para elucidação de um crime para, consequentemente, não acusar um inocente.

Episódio 4: É importante investigar...

No Episódio 4, deixamos transparecer a ideia que o texto apresenta, por meio de uma análise do que foi lido e discutido. Indicamos que exames de DNA são necessários para análises forenses, para não inocentar culpados e não incriminar inocentes. O Quadro 8 mostra as abordagens comunicativas deste episódio. 
Quadro 8-É importante investigar...

\begin{tabular}{|c|c|c|}
\hline $\begin{array}{l}\text { Quem } \\
\text { Fala }\end{array}$ & Trecho & $\begin{array}{l}\text { Abordagem } \\
\text { comunicativa }\end{array}$ \\
\hline M3 & $\begin{array}{l}\text { Então esse caso é um caso real... e o que mostrou ali no } \\
\text { final? }\end{array}$ & $\begin{array}{c}\text { Interativo/de } \\
\text { autoridade } \\
\text { (I/A7) }\end{array}$ \\
\hline E13 & ele foi perdoado porque não era o culpado & \\
\hline M3 & $\begin{array}{c}\text { Isso... e por meio do DNA comprovaram então... viram que } \\
\text { ele não era o culpado }\end{array}$ & $\begin{array}{l}\text { Não } \\
\text { interativo/de } \\
\text { autoridade } \\
\text { (NI/A5) }\end{array}$ \\
\hline M6 & $\begin{array}{c}\text { Mesmo que ele já tinha falado antes do... o cara que fez... } \\
\text { o Lincon tinha também falado que ele era o culpado... e } \\
\text { eles não estavam acreditando... então como ele pediu o } \\
\text { exame... provou que não era ele... ai ele foi solto... }\end{array}$ & $\begin{array}{c}\text { Não interativo/ } \\
\text { de autoridade } \\
\text { (NI/A6) }\end{array}$ \\
\hline M3 & $\begin{array}{c}\text { Por isso que é importante investigar... não só por } \\
\text { exemplo... acusar uma pessoa que é culpada... por mais } \\
\text { que exista muita gente que é culpado e fala que não é... a } \\
\text { gente tem que investigar... então por isso que é onde } \\
\text { entra a química, a biologia, a física, a matemática... então } \\
\text { que vai procurar sempre... éh.: seria as pistas ne... mas } \\
\text { não pistas... os... fugiu a palavra... os traços... as } \\
\text { EVIDÊNCIAS para poder determinar quem é o culpado ou } \\
\text { não... }\end{array}$ & $\begin{array}{l}\text { Não } \\
\text { interativo/de } \\
\text { autoridade } \\
\text { (NI/A7) }\end{array}$ \\
\hline
\end{tabular}

Fonte: Autoria própria (2017).

Com a análise deste episódio obtivemos:

- Utilizamos, de forma não dialógica, o discurso I/A, com objetivo dos estudantes explanarem suas conclusões sobre os entendimentos do desfecho apresentado no texto;

- De forma não-dialógica e de autoridade, utilizamos o discurso NI/A (predominante no Episódio 4), onde explanamos nosso próprio ponto de vista e entendimento sobre o texto. Entendemos que o exposto nesta dimensão, deveria ter sido melhor discutido e aberto para discussão com os estudantes.

Abordagem Comunicativa Utilizada na Atividade

Em cada episódio apresentamos uma sequência de abordagens que se diferem entre si. Entretanto, com base na análise de cada episódio, destacamos a mais utilizada, a fim de realizamos uma análise ampla de cada episódio.

Episódio 1: Nesse episódio discutimos com os estudantes sobre formas de reconhecimento de um suspeito atrelado com as informações do texto e com os próprios comentários dos mesmos. Destacamos a abordagem interativo dialógico, promovendo diálogo e oferecendo informações para o desenvolvimento do contexto.

Episódio 2: Um fator relevante para o discurso nesse episódio foi a questão da cor da pele do acusado, que levou a discussões sobre preconceito, promovendo uma abordagem interativo dialógico. 
Observamos nesse episódio que não desenvolvemos corretamente o discurso, pois ao chamar a atenção de um grupo de estudantes que estavam conversando assuntos não relacionados às discussões do texto, mudamos o foco para a bicicleta que a vítima identificou ser do suspeito acusado. Deste modo, não desenvolvemos a discussão levantada sobre o que levou o suspeito ser preso (I/D6) e, passamos a indagar sobre a bicicleta (I/A4), acreditamos que deveríamos, após a pausa, ter voltado para o questionamento (I/D6) e posteriormente abordar as demais discussões pertinentes ao que foi lido no trecho do texto para esse episódio.

Com a interrupção do episódio, além de termos realizados as observações de forma NI/A, não conseguimos dar continuidade às discussões que logo se cessaram.

Episódio 3: O objetivo da atividade era de promover significados, para os estudantes, sobre DNA a partir das discussões do texto, a fim dos mesmos observarem que o exame de DNA pode ser realizado para elucidar crimes.

Com isto, esse é o episódio central das discussões, pois é nele em que realizamos discussões sobre DNA. Utilizamos a abordagem interativo dialógico, promovendo o discurso interrogando os estudantes sobre o que é o DNA, discutindo as ideias atribuídas pelos estudantes de forma a identificar que o estopim de estudos sobre evolução de DNA serve para que estas situações (acusação equivocada de um suspeito) não ocorram.

Episódio 4: Aqui, intervimos, de forma a rever o desenvolvimento das discussões realizadas, sintetizamos o que foi discutido ao longo dos outros episódios e, apresentamos as próprias conclusões sobre o texto, a abordagem não interativo/de autoridade.

Partindo disto, vemos que as abordagens comunicativas estão:

[...] articuladas como o desenvolvimento do conteúdo do discurso na medida em que progride o desenvolvimento da estória científica, e também como essas abordagens são produzidas por meio de intervenções da professora por meio de diferentes padrões de interação [...] (MORTIMER; SCOTT, 2002, p. 304).

Cada abordagem possui sua especificidade e sua importância no desenvolvimento da estória científica e, apesar de ser importante oferecermos subsídios para que os estudantes produzam seus próprios significados, é o docente que tem como responsabilidade desenvolver a estória (MORTIMER; SCOTT, 2002). A abordagem mais utilizada foi a interativa dialógica, entretanto, destacamos que é fundamental o professor fazer intervenções de dimensão "de autoridade" no ensino de ciências, a fim de oferecer novas ideias no desenvolvimento do discurso, afinal "[...] a linguagem social da ciência é essencialmente de autoridade" (MORTIMER; SCOTT, 2002, p. 302).

Porém, observamos em nosso discurso, que as abordagens não interativas de autoridade são passíveis de análise, pois acreditamos que o professor auxilia no processo de atribuição dos significados dos estudantes, mas é importante que o estudante busque estes significados a partir de discussões em que o professor norteia e não defina significados prontos, estabelecidos do ponto de vista docente, como o que ocorre nas discussões NI/A. 


\section{CONCLUSÕES}

$\mathrm{Na}$ autorreflexão pedagógica, averiguamos que as quatro classes de abordagem comunicativa articulam-se entre si e, que é aconselhável que estas variem no decorrer da aula, havendo tanto dimensão dialógica/não dialógica como interativa/não interativa. Uma vez que, é necessário que haja intervenções do docente para não distanciar o assunto do foco desejado, como forma de avançar o desenvolvimento da "estória científica". O que influencia é o modo que o docente as utiliza no decorrer de sua aula para que os estudantes possam identificar seus significados com base na interação estudante/professor.

Observamos, no decorrer das análises, que utilizamos as quatro classes das abordagens comunicativas, mas com predominância em I/D. Acreditamos que quando há interação com os estudantes, mais precisamente em uma abordagem comunicativa dialógica, auxiliamos na construção dos significados dos estudantes, devido a troca de ideias entre estudantes/estudantes e estudantes/professor.

Entretanto, no decorrer do desenvolvimento da "estória científica" foi necessário realizarmos intervenções de maneira não dialógica para dar andamento no entendimento e na utilização do DNA, para elucidação do crime discutido no texto e, consequentemente, para outras situações que envolvam exame de DNA, como de paternidade. Contudo, percebemos que ao fim da atividade (Episódio 4) fornecemos informações que os estudantes poderiam ter chegado por meio de intervenções dialógicas, para que os mesmos relacionassem as formas de identificação de um suspeito e ainda, fizessem relação com a atividade anterior.

Assim, ao final da análise, podemos considerar relevante que o professor tenha diferentes tipos de abordagens quando em contato com os estudantes e, por isso, o presente trabalho busca contribuir para a formação dos futuros professores do grupo PIBID Química. Ao mesmo tempo em que um professor expõe ideias para a condução de uma atividade, ele deve fazer com que os estudantes participem do processo de ensino e de aprendizagem ao permitir que apresentem suas ideias também, em uma relação mútua de entendimento sobre o que os estudantes pensam e sobre como a discussão pode ter sequência. Em suma, o texto serviu como suporte para analisarmos os posicionamentos como futuros professores na interação com estudantes, apontando ponderações entre pontos positivos e negativos da própria prática pedagógica.

Enfatizamos que houve fragilidades na condução da pesquisa que buscaremos superar, como as falhas na interação com os estudantes, a forma de condução das atividades, entre outras. Essas fragilidades foram pontuadas por meio das abordagens comunicativas de Mortimer e Scott (2002) e, sem a análise apresentada no presente artigo, talvez não perceberíamos pontos que devem ser melhorados na atuação docente. 


\title{
Communicative approach in the classroom: a self-reflection teacher
}

\begin{abstract}
The present work analyzes the communicative approaches in order to develop selfreflection. There have been approaches through an activity developed by the PIBID group (of the Portuguese - Program Institution of Scholarship Initiation), using the discursive analysis of Mortimer and Scott (2002) as methodology, to see how the interactions between students and future teachers of chemistry. For this analysis, we performed the reading and discussion of a text: "Genomics: DNA Forensic Identification" as a way to contextualize the forensic chemistry in a didactic sequence. This activity served as the basis for the understanding of the discursive analysis existing in interaction between students from high school of a Public School in the Paraná State and academics of the subproject PIBID, which we called as pibidianos. The discussions were recorded with audio recorders and later transcribed for analysis. The methods presented in the discursive analysis led us to a selfreflection of teaching practice in the interaction of future teachers of chemistry with high school students from public school of Toledo/PR As the activity was developed by the Group of academics of PIBID, one of the main focuses of this project was to enable the pibidianos experiences on pedagogical practices in the classroom. With that, this activity has allowed these scholars, by means of the communication approaches of Mortimer and Scott (2002), identify the teaching placements in the discussion of a text in order to analyze their actions in the course of the activity.
\end{abstract}

KEYWORDS: Discursive analysis. Teacher training. Forensic DNA. 


\section{AGRADECIMENTOS}

O presente trabalho foi realizado com o apoio da CAPES, entidade do Governo Brasileiro, voltada para a formação de recursos humanos. Beneficiário de auxílio financeiro da CAPES - Brasil.

\section{REFERÊNCIAS}

AMARAL, E. M. R.; MORTIMER, E. F. Uma metodologia para análise da dinâmica entre zonas de um perfil conceitual no discurso da sala de aula. p. 239-296. In: SANTOS, F. M. T.; GRECA, I. M. A pesquisa em Ensino de ciências no Brasil e suas metodologias. Coleção: Educando em ciências. 2ed. Ed. Unijuí, 2011.

BOGDAN, R. \& BIKLEN, S. Investigação qualitativa em educação. Tradução: Maria João Alvarez; Sara Bahia dos Santos; Telmo Mourinho Baptista. Portugal: Porto Editora, 1994.

BRASIL. Orientações curriculares para o ensino médio. Ciência da Natureza, Matemática e suas Tecnologias, v. 2, 2006. p. 1-137. Disponível em: <http://portal.mec.gov.br/seb/arquivos/pdf/book_volume_02_internet.pdf> Acesso em: 29 abr. 2017.

IMBERNÓN, F. Formação docente e profissional: formar-se para a mudança e a incerteza. 3. ed. São Paulo: Cortez, 2002.

MORTIMER, E. F.; SCOTT, P. Atividade discursiva nas salas de aula de ciências: uma ferramenta sociocultural para analisar e planejar o ensino. Investigações em Ensino de Ciências, Espanha, v. 7, n. 3, p.283-306, 2002. Disponível em: <http://www.if.ufrgs.br/ienci/artigos/Artigo_ID94/v7_n3_a2002.pdf>. Acesso em: 06 fev. 2017.

NÓVOA, A. Para uma formação de professores construída dentro da profissão. Lisboa, Portugal, s/a, p. 1-10. Disponível em:

<http://www.revistaeducacion.educacion.es/re350/re350_09por.pdf>. Acesso em: 05 abr. 2017.

NUNES, C. M. F. Saberes docente e formação de professores: um breve panorama da pesquisa brasileira. Educação \& Sociedade, ano XXII, n. 74, abr., 2001, p. 2742. Disponível em: <http://www.scielo.br/pdf/es/v22n74/a03v2274.pdf>. Acesso em: 05 abr. 2017. meio da experimentação. Química Nova na Escola, 2014, p. 1-9. Disponível em: 
<http://qnesc.sbq.org.br/online/prelo/RSA-40-13.pdf> Acesso em: 12 de abr. 2017.

SOUZA, A. L.; CAMPOS, M. L.; BENITE, A. M. C. Estudos sobre a utilização da comunicação não verbal na aula de Química. Química Nova na Escola, v. 36, n. 2, p. 150 - 161, maio 2014. Disponível em:

<http://qnesc.sbq.org.br/online/qnesc36_2/11-PE-22-12.pdf>. Acesso em: 29 de abr. 2017.

SOUZA, V. S. Ciência e miscigenação racial no início do século XX: debates e controvérsias de Edgard Roquette-Pinto com a antropologia física norte americana. História, Ciências, Saúde. Manguinhos: Rio de Janeiro. v. 23, n.3. 2016. p.597-614.

WATSON, J. D.; BERRY, A. Identificação Genômica: O DNA Forense. In: WATSON, J. D.; BERRY, A. DNA O Segredo da Vida. Tradução: Carlos Afonso Malferrari. São Paulo: Companhia das Letras, 2005. p. 283 e 284.

Recebido: 29 jul. 2017

Aprovado: $18 \mathrm{dez} .2017$

DOI: $10.3895 /$ actio.v2n3.6815

Como citar:

MIOLLA, D.; ENGELMANN, G. L. Abordagem comunicativa em sala de aula: uma autorreflexão docente. ACTIO, Curitiba, v. 2, n. 3, p. 115-132, out./dez. 2017. Disponível em: <https://periodicos.utfpr.edu.br/actio>

Acesso em: XXX.

Correspondência:

Diullye Miola

Universidade Estatual do Oeste do Paraná - Unioeste. Rua da Faculdade, 645 - Jardim La Salle

85903-000 - Toledo, Paraná, Brasil.

Direito autoral: Este artigo está licenciado sob os termos da Licença Creative Commons-Atribuição 4.0

Internacional.

\section{(c) (1)}

